\title{
Effect of a Protein-Energy Supplement of Low Consumption with Coconut Pulp Expeller (Acrocomia aculeata) of Beef Cattle at Pasture
}

\author{
Julio Gonzalez'1, Javier Kanazawa², Patricia Coronel2 ${ }^{2}$ Gregorio Presentado², \\ María Paz Corrales ${ }^{1}$, Patricia Criscioni ${ }^{1}$, Oscar Luis Valiente ${ }^{{ }^{*}}$
}

\footnotetext{
${ }^{1}$ Department of Bromatology, Nutrition and Animal Feeding, Faculty of Veterinary Sciences, National University of Asunción, Asunción, Paraguay

${ }^{2}$ Department of Animal Production, Faculty of Veterinary Sciences, National University of Asunción, Asunción, Paraguay

Email: *ovaliente@vet.una.py
}

How to cite this paper: Gonzalez, J., Kanazawa, J., Coronel, P., Presentado, G., Corrales, M.P., Criscioni, P. and Valiente, O.L. (2020) Effect of a Protein-Energy Supplement of Low Consumption with Coconut Pulp Expeller (Acrocomia aculeata) of Beef Cattle at Pasture. Open Journal of Animal Sciences, 10, 528-534.

https://doi.org/10.4236/ojas.2020.103033

Received: June 5, 2020

Accepted: July 13, 2020

Published: July 16, 2020

Copyright $\odot 2020$ by author(s) and Scientific Research Publishing Inc. This work is licensed under the Creative Commons Attribution International License (CC BY 4.0).

http://creativecommons.org/licenses/by/4.0/

\section{(c) (i) Open Access}

\begin{abstract}
The purpose of this study is to evaluate the effect of a low consumption protein-energy supplement that incorporates $15 \%$ of coconut pulp expeller in bovine animals. These pasture fattening cattle were checked on daily weight gain, supplement consumption and efficiency of pasture use. This study was carried out in a livestock establishment in the Department of Concepción, Paraguay. A total of 108 animals were selected; castrated male bovines, $342 \pm$ 30.2 of body weight (BW), age average 28 months, Nelore breed distributed in 2 treatments (T1 and $\mathrm{T} 2$ ): $\mathrm{T} 1=42$ animals; control group (pasture + conventional mineral salt) and $\mathrm{T} 2=66$ animals; treatment group with a protein-energy supplement (pasture + protein-energy supplement with minerals). In both treatments, the animals grazed on pasture of Brachiaria brizantha cv. Marandú and Panincum maximaun cv. Tanzania used a system of pasture rotation of $1-3$ days of occupation and 35 - 40 days of rest. The average daily weight gain (DG) was 0.82 and $0.83 \mathrm{~kg} / \mathrm{day}(\mathrm{p}>0.05)$, the supplement consumption was 0.1 and $0.28 \mathrm{~kg} /$ day per animal and the \% disappearance of the biomass of 18 and $23 \%$ for $\mathrm{T} 1$ and $\mathrm{T} 2$, respectively. In conclusion, there was no evident effect on DG of protein-energy supplementation.
\end{abstract}

\section{Keywords}

Supplementation, Protein-Energy, Mineral, Bovine, Fattening

\section{Introduction}

Beef cattle production constitutes one of the most important sectors of Para- 
guayan economy and occupies $39 \%$ of the land in the country. In this sense, production on extensive grazing systems is predominant, which is carried out on native and cultivated pastures, fundamentally on the first one [1].

Cattle raising versus cultivation compete for the use of the land; it caused the first to look for more efficiency in the whole productive cycle, mainly in the cattle fattening stage [2].

For cattle termination in the extensive system of production, the order of priorities based on existing limitations must be taken into consideration, especially when the quality of fodder offers is limited, due to the fact that they experience accelerated growth and therefore, greater changes in their chemical composition as the summer season advances, at a time that it may coincide with a rotating system when the animals arrive to consume them, a situation when the pastures have a high level of neutral detergent fiber (NDF), detergent acid (ADF) and lignin. On the other hand, during the dry season, the quality of the pasture is essentially low, with a high fiber content and meager in nitrogen [3] [4] [5].

This is why in beef cattle production one must look for alternatives in supplements which allows for ruminal function to have a harmonius balance [6] which lead to alternatives such as low consumption energy-protein supplements which generally have, as main ingredients, corn and soybeans that may present limitations of high acquisition prices of these raw materials.

An alternative raw material for ruminant feed could be Coconut Pulp Expeller (Acrocomia aculeata), even though up till date, there is very little information in the literature for its use, it could partially substitute traditional energy sources such as corn, taking into account its chemical composition with an oil residual of $15 \%$ [5], especially in fattening bovines and with a more competitive price. Paraguay is a country noted for having an abundant natural production of Acrocomia aculeata, besides being one of the few countries where it is industrially processed [7]. Due to these motives, in this study it was posed as a main objective to evaluate the effect of a protein-energy supplement of low consumption incorporating $15 \%$ of coconut pulp expeller over daily weight gain, supplement feed and pasture use efficiency.

\section{Material \& Methods}

\section{Animals and Feeding}

The study was carried out in a cattle raising establishment that fattens bovines on cultivated pasture located in the Department of Concepción, Paraguay $\left(23^{\circ} 19^{\prime} 45.6^{\prime \prime} \mathrm{S} 57^{\circ} 10^{\prime} 43.8^{\prime \prime} \mathrm{O}\right) .108$ bovines, castrated males of Nelore breed, with an average weight at the start of the study of $342 \pm 30.2 \mathrm{~kg}$ and 28 months of average age in the fattening stage. They were divided in two groups (Treatments: T). T consisted in two different types of supplements; T1 (control): grass + conventional mineral salt ( $\mathrm{n}=42$ bovines) and T2: grass + protein-energy supplement of low consumption with 15\% inclusion of Coconut Pulp Expeller ( $\mathrm{n}=$ 66 bovines), that were formulated based on reccomendations [8] (See Table 1). 
Table 1. Chemical concentration (for each $\mathrm{kg}$ of product) of conventional mineral salt (T1) and of protein-energy supplement plus minerals with $15 \%$ coconut pulp expeller (T2).

\begin{tabular}{ccc}
\hline Components (unit) & T1 Concentration & T2 Concentration \\
\hline Calcium (g) & 140 & 32 \\
Phosphorus (g) & 60 & 20 \\
Sodium (g) & 140 & 90 \\
Magnesium (g) & 15 & 6 \\
Sulphur (g) & 20 & 15 \\
Zinc (mg) & 3000 & 1000 \\
Manganese (mg) & 2000 & 500 \\
Copper (mg) & 1000 & 500 \\
Cobalt (mg) & 90 & 30 \\
Yodine (mg) & 90 & 30 \\
Selenium (mg) & 20 & 7 \\
Crude Protein (g) & NC & 350 \\
Total Digestible Nutrients (g) & NC & 350 \\
Metabolizable Energy (Kcal) & NC & 1.500 \\
\hline
\end{tabular}

NC: does not contain.

The bovines grazed during 68 days (February to April 2019) on cultivated pastures of Brachiria brizantha cv. Marandú y Panincum maximun cv. Tanzania in a rotating system with grazing periods of 1 to 3 days and rest from 35 to 40 days (according to the paddock and grass production) (See Table 2 Chemical Composition of sample grass).

\section{Measurements}

Supplements were offered in feeders ( $30 \mathrm{~cm}$ linear per animal), both those offered as well as those that refused were weighed daily. Animals were weighed on a mechanical scale at the beginning and at the end of the study period (68 days), samples of the grass offered were taken one day before the entry and on the same day of exit of the animals from their respective paddocks with the technique of square throw $(1 \times 1$ meter $)$ proposed [9].

A daily weight gain (DG in $\mathrm{kg} /$ day) for each animal, and by group daily intake of the supplement per animal by treatment (DI in $\mathrm{kg}$ /day) were estimated; initial offer of biomass fodder refused post-grazing was measured for each treatment (in $\mathrm{kg} / \mathrm{ha}$.) whereas the missing biomass fodder after grazing was measured in percentage (\%).

\section{Chemical Analysis}

Grass samples offered were ground in a hammer mill going through a sieve of $1 \mathrm{~mm}$ in diameter and dried in a forced ventilation heater at $105^{\circ} \mathrm{C}$ during 48 hours, whereas PB was determined following the Kjendahl method using a Quimis Digestor \& Destilator model Q327E26B [10]. ADF and NDF were analyzed according to [11]. 
Table 2. Chemical composition of sample grass (\%).

\begin{tabular}{cc}
\hline Chemical Composition $^{1}$ & Values (\%) \\
\hline CP & 5.2 \\
ADF & 71.6 \\
NDF & 39.6 \\
\hline
\end{tabular}

${ }^{1}$ CP: Crude Protein, ADF: Acid Detergent Fiber, NDF: Neutral Detergent Fiber.

\section{Statistics Analysis}

Results of daily weight gain were compared statistically by the Student T method using the statistics package Statistx 9.0, with an alfa error level of 0.05. Offer and refusal of biomass fodder, as well as the percentage of missing biomass fodder, both of them calculated per treatment, were contrasted by quantitative comparisons.

\section{Results and Discussion}

Corresponding results of average daily weight gain (DG) and average daily supplement intake per animal (DI) with their standard deviations (SD) for each treatment are shown on Table 3, where DG was almost identical between treatments, being the difference not statistically significant $(p>0.05)$. DI observed per treatment was almost triple in $\mathrm{T} 2$ in relation to $\mathrm{T} 1$.

DG results in this study were high for pasture conditions and very superior to what [12] reported both for mineral supplements $(0.24 \mathrm{~kg} / \mathrm{day})$ as well as with the protein-energy block that used $(0.33 \mathrm{~kg} /$ day $)$ working with weaning cows on native pastures, carried out between the months of July and October. Similarly, the results were higher than those reported by [13] and [14], both with protein salt supplement $(0.48$ and $0.38 \mathrm{~kg} /$ day $)$ as well as with a protein-energy concentrate $(0.32$ and $0.55 \mathrm{~kg} /$ day, respectively) both carried out in bovines grazing on native pastures. Also, the result was far superior than the result recorded by [15] of $0.33 \mathrm{~kg} /$ day in heifers getting mineral supplements on native pastures, as well as the results obtained by [16] of $0.37 \mathrm{~kg} /$ day on supplements with protein mineral salt and of $0.21 \mathrm{~kg} /$ day on cattle receiving conventional mineral salt; both cases on native pastures. Likewise, DG was superior to those observed by [17], either on groups receiving $0.1 \%$ protein salt of live weight $(0.592 \mathrm{~kg} /$ day $)$ and $0.05 \%$ live weight $(0.608 \mathrm{~kg} /$ day $)$, in the research carried out in the Paraguayan Chaco on steers on native pastures. However, [18] reported closer results to the present study, in steers on native pasture during the summer period without shade $(0.650 \mathrm{~kg} /$ day $)$ and with shade $(0.529 \mathrm{~kg} /$ día $)$, both groups had free access to protein blocks (with $28 \%$ raw protein).

On Table 4, it is shown the offer, refusal and a percentage of average miss of the biomass fodder (in the form of PDM) of the respective pastures utilized by bovines of each treatment (T1 and T2), where we can tell that the initial MSP offer was closer to $2.000 \mathrm{~kg} / \mathrm{ha}$. The refusal left was fairly important in both treatments and next to $1.500 \mathrm{~kg} / \mathrm{ha}$ of PDM. Missing percentage was a little 
Table 3. Average daily weight gain (DG) and average daily supplement intake per animal (DI) with standard deviation (SD) expressed in $\mathrm{kg} /$ day for T1 (grass + conventional mineral salt) and T2 (grass + protein-energy with minerals supplement).

\begin{tabular}{ccc}
\hline Treatment & DG \pm SD $(\mathrm{kg} /$ day $)$ & DI \pm SD $(\mathrm{kg} /$ day $)$ \\
\hline T 1 & $0.82 \pm 0.164$ & $0.10 \pm 0.042$ \\
T 2 & $0.83 \pm 0.191$ & $0.28 \pm 0.075$ \\
\hline
\end{tabular}

Table 4. Offer, refusal (kg/ha) and percentage (\%) of missing biomass in the form of partially dried matter (PDM) of treatments (T1 and T2).

\begin{tabular}{cccc}
\hline Treatment & Initial Offer & Refusal Post-grazing & \% of missing biomass \\
\hline T1 & 1.933 & 1.550 & 18 \\
T2 & 1.966 & 1.494 & 23 \\
\hline
\end{tabular}

higher in the ones that consumed protein-energy supplements (T2) (23\% vs. $18 \%)$.

These percentages of missing biomass fodder that mostly were a consequence of the intake the bovines had, in the present study, were relatively low probably due to the low pressure of the applied pasture, which if it is compared to ranges from $33 \%$ to $66 \%$ of missing biomass among the lower and higher pressures of grazing reported by [19], and by almost $40 \%$ to $70 \%$ variations in the percentage of utilization of available fodder, that were increased as the rest period of grazing increased, according to [20].

Thus, it can be concluded that DG for pasture conditions was high, that the utilization of protein-energy supplementation of low consumption did not affect it, even though it positively influenced the percentage of missing biomass fodder.

\section{Conflicts of Interest}

The authors declare no conflicts of interest regarding the publication of this paper.

\section{References}

[1] ARP (Asociación Rural del Paraguay) (2010) Manual compendio de la ganadería paraguaya. Mariano Roque Alonso, Paraguay, 431 p.

[2] Alassia, G., Gatti, Z. and Stefanazzi, D. (2008) Engorde de bovino a corral (en línea). Facultad de Agronomía, Universidad Nacional de La Pampa, La Pampa. http://www.agro.unlpam.edu.ar/licenciatura/diseno/engordebob.pdf

[3] Shirley, R.L. (1986) Nitrogen and Energy Nutrition of Ruminants. Academic Press, Inc., Orlando, 37 p. https://doi.org/10.1016/B978-0-08-092579-0.50020-6

[4] Minson, D.J. (1990) Forage in Ruminant Nutrition. Academic Press, San Diego, 483 p.

[5] Stanley, W. (2013) Degradabilidad in situ y fermentación ruminal en ovinos en pastoreo que reciben suplementos de expeller de almendra y de pulpa de coco (Acrocomia aculeata). Tesis (Mg. Sc.). Zaragoza, Facultad Veterinaria Universidad de Zaragoza, España, 83 p. 
[6] Preston, T. and Leng, R. (1989) Aspectos básicos y aplicados del nuevo enfoque sobre la nutrición de rumiantes en el trópico. Consultoría para el Desarrollo Integrado en el Trópico (CONDRIT), Cali, $312 \mathrm{p}$.

[7] Poetsch, J., Haupenthal, I., Lewandowski, I., Oberlander, D. and Hilger, T. (2012) Acrocomia aculeata-A sustainable oil crop (en linea). Rural21 Scientific World, Tubigen. http://www.researchgate.net

[8] BR-CORTE (2016) Tabla Brasilera de exigencias nutricionales. Editores Sebastian Valadares Fhilo et al. $3^{\text {a }}$, Luiz Fernando Costa e Siva, Mateus Pies Gionbelli, et al. $3^{\text {a }}$ ed. UFV, DZO. Viçoza (MG). 327 p.

[9] Mejis, J.A.C., Walters, R.J. and Keen, A. (1982) Sward Methods. In: Leaver, J.D., Ed., Herbage Intake Handbook, The British Grassland Society, Kenilworth, 11-36.

[10] AOAC (2000) Official Methods of Analysis. 16th Edition, Association of Official Analytical Chemists, Washington DC.

[11] Robertson, J.B. and Van Soest, P.J. (1981) The Detergent System of Analysis and Its Application to Human Foods. In: James, W.P. and Theander, O., Eds., The Analysis of Dietary Fibre in Food, Marcel Dekker, New York, 23-158.

[12] Nuñez Rios, C.M. (2011) Efecto de la utilización de un suplemento proteico energético y mineral (bloque multinutricional), sobre la ganancia de peso en desmamantes hembras cebuínas a campo natural, en establecimiento ganadero. Tesis (Doctor en Ciencias Veterinarias). Orientación Producción Animal. FCV. UNA, San Lorenzo, $64 \mathrm{p}$.

[13] Bogado Acevedo, J.D. (2014) Efecto de la suplementación con sal mineral proteinada y con un concentrado proteico-energético sobre la ganancia diaria de peso en vaquillas, recriadas en pasturas. Tesis (Doctor en Ciencias Veterinarias). Orientación Producción Animal. FCV. UNA, San Lorenzo, 40 p.

[14] Macchi, F.R., Peralta, J.R., Valiente, O.L. and Alvarez, R. (2018) Efecto de la suplementación con sal mineral proteinada maíz y concentrado comercial sobre el peso vivo y la ganancia de peso en bovinos desmamantes alimentados a base de Brachiaria brizantha cv Marandú y Mg4 (en línea). Universidad Nacional de Asunción, San Lorenzo.

http://scielo.iics.una.py//scielo.php?script=sci arttext\&pid=S2226-17612018000100 $\underline{022 \& l a n g=e s}$

[15] Imas Segovia, N.R. (2016) Efectos de la suplementación mineral sobre la ganancia de peso en vaquillas bajo condiciones naturales de pastoreo en el departamento de misiones. Tesis (Doctor en Ciencias Veterinarias), Orientación Producción Animal. FCV. UNA, San Lorenzo, $34 \mathrm{p}$.

[16] Lesmo Ferreira, A.R. (2008) Estudio del efecto de la suplementación con sal mineral proteinada sobre la ganancia de peso de novillos en engorde durante la época crítica. Tesis (Doctor en Ciencias Veterinarias), Orientación Producción Animal. FCV. UNA, Concepción, 46 p.

[17] Digalo Lafuente, H. (2015) Efecto de la suplementación proteica sobre la ganancia diaria de peso en novillos cruza Brangus en un sistema de invernada en el Departamento de Presidente Hayes. Tesis (Doctor en Ciencias Veterinarias), Orientación Producción Animal. FCV. UNA, San Lorenzo, 75 p.

[18] Rovira, P.J. and Velazco, J.I. (2011) Desempeño productivo y conducta de novillos a campo natural con suplementación proteica y sombra artificial en verano (en línea). Instituto Nacional de investigación Agropecuaria, Montevideo.

http://www.produccion-animal.com.ar/informacion tecnica/suplementacion prote ica y con nitrogeno no proteico/75-sombra proteina.pdf 
[19] Ohanian, A., González, S., Saroff, C. and Pgliariccii, H. (2007) Efecto de la asignación de forraje en la producción primaria y los componentes productivos de un cultivo de triticale ( $X$ triticosecale Wittmack). APPA-ALPA-Cusco, Sitio Argentino de Producción Animal, Perú.

http://www.produccion-animal.com.ar/produccion y manejo pasturas/pasturas c ultivadas verdeos invierno/44-OHANIAN-Triticale Prod.pdf

[20] Armúa Rosa, A. (2013) Efecto de la frecuencia de pastoreo sobre la productividad de un campo natural. Tesis (Ingeniero Agronomo), Facultad de Agronomía, Universidad de la República, Montevideo, 140 p. 